\title{
Carceral Imaginaries
}

\author{
Segregating Space and Organs through \\ National Reproductive Norms
}

\begin{abstract}
This article examines the carceral imaginaries that emerge from the late capitalist structure of organ donation as an issue of short supply. This piece explores this issue through the lens of spatial segregation, arguing that carceral imaginaries are spaces of luxury where donors are segregated from recipients and are thereby legally murdered. The focus is Ninni Holmqvist's novel The Unit (2008) where the future is structured through gender equality but reproductive normativity. Donors are segregated away in the luxurious unit because they have not reproduced. Having not produced future generations of labourers, these donors must contribute to the nation by donating their body parts to the reproductive - and therefore productive - members of the nation. Focusing on Sweden's history of eugenics and on gender equality, this article argues that the very space of care, namely the clinic, which facilitates life-saving treatments also subjects whole populations to violence and death through reproductive norms. Finally, it suggests that space is both that through which bodies move, but also the body itself. That is, the segregation of the body's parts and the idea that space may be divided by borders are mutually constitutive and found both the restrictions of bodily movement through space and murder as the gift of life.
\end{abstract}

Keywords: organ transplantation, reproduction, Ninni Holmqvist, The Unit (Enhet), segregation, imaginaries 
Is it surprising that prisons resemble factories, schools, barracks, hospitals, which all resemble prisons? (Foucault 1995 [1975], 228)

The postulate of a founding heterosexuality must also be read as part of the operation of power [...] such that we can begin to ask how the invocation of such a foundation works in the building of a certain fantasy of state and nation. (Butler 2004b, I24)

\section{The body and its politic}

BIOTECHNOLOGIES ARE REPEATEDLY hailed as the innovative means through which lives are extended and saved (Laing \& Lubin 2020; National Health Service. n.d.a. and n.d.b.). ${ }^{\mathrm{T}}$ Within this context, "organ grafting has earned its place as the medical miracle of the [twentieth] century" (Stark I996, 6). Transplant surgeons have heralded a technologically dependent notion of death where the "living cadaver" (Hogle I999, 66) haunts the common imaginary. Here, the topography of the clinic is one where the dead remain breathing to enable the lives of others, as well as where donors are held in an uncertain state between life and death through the transference of matter-as-donated-organ. Because organ grafting promises to save the lives of an ever-growing number of people, there is in clinical and media contexts a focus on how to increase supply (Organ Donation Taskforce 2008). The dire consequences of such late capitalist narrative forms have been explored by many critics (Cohen 2005; Scheper-Hughes 2005) and increasingly in contemporary literature and film. Organ transplantation as a spatialised practice - that is, a biomedical procedure that conceptualises the body as a space comprised of recyclable body parts - features in film and novels largely as a violent, deadly practice that either aims to maximise profit or to find organs for recipients at any cost (Dimaline 20I7; Sapochnik 2010; Ishiguro 2005; Frears 2002). Violence towards donors or exploitation of donors and recipients, which could be described as "biocapital" (Sunder Rajan 2006), is integral to the very spaces imagined as caring and curative. The necropolitical dimensions of transplantation could be described as the exploitative aspects of wanting to extend life, 
as well the problems of the redefinition of death in the medical arena (Cooper \& Waldby 2014; Cooper 2008; Lock 2002). Building on this research, this article examines the ways in which contemporary dystopian fiction portrays this need for an ever-growing number of organs through the lens of spatial segregation. I focus on Ninni Holmqvist's The Unit (2008) to capture how dystopian fiction imagines a future where reproductive normativity is an institution of violent care. That is, in this novel the very space of care, namely the clinic, which facilitates lifesaving treatments also subjects whole populations to violence and death through reproductive norms. In this sense, clinics are not simply places for positive medical interventions, but the very means through which segregation is practiced and a deadly politics administered. ${ }^{2}$ However, integral to this argument is the further aim of examining how the body itself is spatialised. That is, I argue that the visceral body in these texts is imagined as composed of parts (organs, for example) and functions (reproduction being the main focus here) - rather than say an inseparable organism that functions interdependently with others both inside and outside what we call the self and whose hormones and parts cannot be reduced to a single supposedly biological function - and therefore constitutes understandings of space as defined by borders, divisions and segregation. The segregation of the body's parts and the idea that space may be divided along specific lines are mutually constitutive and found the restrictions of bodily movement through space and murder as the gift of life.

In order to examine the relationship between space and care, this article engages with three leading theorists on space and biopolitics: Michel Foucault (I995 [1975], 2006 [2003]), Giorgio Agamben (1998) and Achille Mbembe (2019, 2003). I offer an analysis of their work to capture how space constitutes health and care. Here, the idea of a healthy body is tied to the sovereign ability to let life endure, even when this eventually kills the person. However, an important distinction that this article makes from their work is that while clinical spaces in the selected novel convey new ways of disciplining bodies, they do not simply lead to docile bodies, but rather enable the enhancement of life itself 
(including for donors while they are alive). I want to expand their theories of space through two dimensions: I) a focus on reproduction as central to a biopolitics of life and 2) segregation as a bodily and spatial act. In so doing, I explore how this state of exception is instituted through an ideal of reproduction. Spatialising and thereby segregating donors from recipients, the (dispensable) beings from the (needed) humans, serves to establish a hierarchy of being where reproduction gives value and definition to the human. To this extent, this article argues that the institutionalisation of a national state of exception is made possible through reproductive ideals which differentiate those who matter (reproductive humans) from those whose bodies are valuable only for their matter. In exploring how body parts come to be viewed as vitality for others, I turn to the idea of "carceral imaginaries" (Benjamin 2019; Shedd 2015, 20Ir) to capture how prisons, clinics, schools and even homes constrain bodily movement through space and the mobility of one's body parts as productive life to others and therefore not as death to self. I want to show how carceral imaginaries in transplant fiction are not simply prisons or hospitals/clinics, as we see in Foucault's work. Instead, they are often luxurious spaces of (sexual and intellectual) freedom, where state-sanctioned murder is covered over by an environment experienced and understood as caring. This article therefore explores how the literal spatial segregation of donors from recipients is transposed on to the body to justify separating organs from their bodies. If the person is not a part of reproductive society, then their organs are parts for reproductive others. Space is this movement between society, the institution and the body, and thus segregation is legal murder designed to extend the lives of others. In other words, separating the body from the body politic (and how these are experienced and imagined) becomes almost impossible in a world where incarceration is a luxurious death of self but, importantly, life for others.

My reading of The Unit aims to highlight how contemporary policies on equality, reproduction and access to state support more broadly, particularly when framed through a feminist discourse, cover over violent outcomes. My intention is therefore to explore how the organisation of 
life and death, whether this be in a Swedish novel or the current experience of the global pandemic of COVID-I9, comes to be framed through a segregation of people and their parts. My analysis of how the novel portrays equality policies through reproduction is queer insofar as I interrogate the assumption that equality results in equal access to resources and all lives as equally valuable. On the contrary, my queer reading of the novel shows the violence of national discourses that outlaw gender and sexual norms, but keep in place institutional violence against those who do not reproduce. Indeed, I argue that the novel is queer in its representation of reproductive norms permitting the incarceration of those who do not or cannot reproduce. Queer is the interrogation of feminist ideas that become policies in order to show how easily state and national violence may be masked by feminist and LGBTQ+ gains. ${ }^{3}$ In this article, queer is a mode of reading the novel closely (McCormack 202I, 20I4; Freeman 20Io), as well as a way of examining how we might interrogate and resist the deadly organisation of life through segregation. This is not a hopeful novel, and my reading of it explores why resistance is generally closed down. Therefore, queer functions as an undoing of institutional norms and a revealing of their deadly function (Butler 2004b), as well as an exploration of the role of art in reimagining and putting into place less violent modes of belonging.

\section{Carceral imaginaries and health care}

bell hooks' analysis of belonging captures how space is a structure of power, determining of and determined by the bodies within and passing through it: "Do you believe that space can give life, or take it away, that space has power?" (2009, I2I). Space is thus tied to - we might say constitutively bound with - the possibility of life and its end. The state of exception, bare life, is the limit of sovereignty where persons can be killed without the act being considered murder. This non-legally protected life, zoe, captured for Agamben in the modern architectural structures of the state-sanctioned death camps, is opposed to bios, the state, law and institutionally guarded human life contained within the moral political order. In Agamben's words: 
The camp is the space that is opened when the state of exception begins to become the rule. In the camp, the state of exception, which was essentially a temporary suspension of the rule of law on the basis of a factual state of danger, is now given a permanent spatial arrangement, which as such nevertheless remains outside the normal order. (I998, I68-9)

Agamben stresses that the state of exception is enforced through the law, the very law that is suspended. In the selected novel, the topography of the clinic is the extra-legal right to the organs of others as a space outside of legal society that benefits those within that society legally. A shift in space to the unit results in the removal of life: one will now live solely to donate one's organs to the reproductive and therefore productive citizens.

Foucault asserts, "[It] was the taking charge of life, more than the threat of death, that gave power its access even to the body" (I990 [I978], I43). The Unit testifies to the twenty-first century problematic of how the state and its powerful arms, including health care institutions, gain access to, control and ultimately kill humans without committing murderous crimes. On the one hand, we see how it may be possible to murder people for health reasons without it being illegal, even while murder is illegal. On the other hand, what such twenty-first century novels (e.g. Ishiguro 2005) tackle is not a straightforward violent process of deadly torture, but environments where life flourishes, where luxury abounds and where healthiness is the aim. Indeed, what contemporary dystopian fiction reveals is a biopolitical order of care that ensures life endures through a practice of healthiness and luxury, and in so doing these spaces - clinics - produce bodies that are ideal as matter for others, for saving the lives of others. These donor populations are segregated away from potential future recipients, revealing what Mbembe (2019, 2003) calls "death-worlds". These are "new and unique forms of social existence in which vast populations are subjected to conditions of life conferring upon them the status of living dead" (Mbembe 2003, 40). The term "living dead", in the context of this novel, captures how donors are kept alive solely for their organs and are thus socially dead but biomedically 
necessary. The living dead thrive in these institutions of care, because their bodies are precious to the lives of others. Yet, in the selected novel, biomedical and state institutions do not "dictate" (Mbembe 2003, II), rather they democratically encourage a state of exception. The donors are bare life, but we should not equate bare life with lack of resources or even daily violence; while most medical subjects eventually experience the torture of repeated drugs trials and organ donations, their days are marked by a somewhat healthy and, what they experience as, free existence. To this extent, biopolitics is the control of one's body through a spatialised segregation of care, where one lives well, but solely so that others can have their lives extended.

While I bring these three critical thinkers together, it should be clear that their work is divergent and diverse. Mbembe brings a critical dimension to biopolitics through his focus on European colonialism, and in so doing links his work back to that of James Baldwin (1963) in showing how critical analyses of the Holocaust death camps - such as that of Agamben - often ignore how such practices have occurred throughout history, particularly through the mass enslavement and genocide of Black people during European colonial rule. ${ }^{4}$ However, Mbembe engages very little with health in any direct way, although he does acknowledge this as central to the tactics of power (2003, 23 and 29). Agamben has been criticised for his cursory engagement with health, particularly his problematic classification of those living in a coma (Agamben 2003, I64-65; Chouinard et al. 2010), but his work unlike that of the other two directly - albeit briefly - engages with organ transplantation. What I see as important is how bringing together the work of all three emphasises that the creation of space, including spaces of health and care, is a sovereign act of power that may be mobilised to constrain whole populations and to subject them to technologies of life in ways that instantiate new definitions of life and death. Furthermore, where Foucault insists on a direct tie between architecture and the power exercised in health care, as well as stressing the ties between prisons, schools, clinics and hospitals (Foucault 1995 [1975], 228), Agamben reveals how spaces may operate legally outside 
the law and thus how segregation is a spatialised legal vacuum where torture, violence and murder may have no legal ramifications, despite the law of that country. Mbembe looks at our contemporary moment to show how power is spatialised via more than literal architecture. That is, where both Agamben and Foucault focus on literal divisions and/or structures (e.g. death camps and clinics), Mbembe analyses a politics of the ground, the space beneath the earth and the space above the ground. I therefore bring together and extend these theoretical discussions to argue that the biopolitics of space in The Unit is a sovereign act on space - through segregation - that moves across and within bodies to produce categories of those whose lives are productive and therefore worthy of life and those who may be killed legally. Segregating society is founded upon the need to segregate organs as matter for the lives of others, and segregating donors from recipients facilitates legal murder.

While organ donation and other biotechnological innovations that are promoted as lifesaving may appear as antithetical to the carceral system, Anne Pollock (2015) explores how organ donation is tied to the prison in the US. She cites the case of two African American sisters, Gladys and Jamie Scott, who were released from jail on the condition that Gladys donate her kidney to her seriously ill sister. This disturbing case captures how the "prison imposes biological control on prisoners" (Pollock 2015, 25I) and how "the prisoner's body itself is always part of the payment [of debt to society]" (Pollock 2015, 259-60). Pollock defines the prison as "the organizing of bodies in space" (Pollock 2015, 265 ) that institutes health care in often hugely limited and problematic ways and, here, as a possible condition for release. Law reaches into the body to enforce biological control where one must sacrifice a kidney for limited freedom. Biopolitics is this spatialisation of the body as a series of discreet entities (in this case organs) that may be mined for a perceived greater good and as a debt to society. While such an example may be specific to the US and potentially read as far from the Swedish context of the novel, I read this segregation of the body part from the self as one way in which carceral practices are integral to - and 
sometimes constitutive of - health care. Lisa Diedrich argues that the organisation of patients in space is often not about "the needs of the patients, but rather [about creating] the most efficient organization for supervision" (2007, II). In other words, building on Foucault, when people are organised in space, and those people are surveilled by "the gaze of authority", then what we have is a "carceral' institution" (2007, II). She concludes that "[where] health is concerned, documentation forms the basis for differentiation, classification, and segregation" (2007, I2). These "carceral imaginaries" - as Ruha Benjamin (2019, 5), building on Carla Shedd's sociological analysis of a "carceral continuum" (2015, 20II), describes such apparatus - capture how segregation, bodily sacrifice, early death, and other discriminatory and deadly practices may be instituted not only through the imprisonment of populations but also through health care (and other supposedly caring sites, policies and practices).5 Benjamin states, "Subjugation, after all, is hardly ever the explicit objective of science and technology; instead noble aims such as 'health' and 'safety' serve as a kind of moral prophylactic for newfangled forms of social control" (2019, I3). It is this assumed inherent good of health and care - and health care - that I not only problematise but that I agree covers over the violence of care itself. More specifically in relation to space, I concur with Britt Rusert who, building on Colin Dayan's work (2013), argues:

[Care] has been used by the [US] state to justify coercion and legitimate state violence. "Care" and the interventions made under its name are the perfect cover for intensive surveillance, oversight, and exploitation, especially in a biopolitical regime in which life must be supported - and indeed produced - at all costs, even when it tends toward the death of individual subjects. (Rusert 20I9, 38)

Care and health are spatialised as methods of biopolitical power that ensure life continues even when the outcome is death. Life is supported through measures that control the mobility of not only individuals and populations but also of body parts, including bodily functions. As Pol- 
lock shows, the body may be mined for health purposes that claim to make life endure, and such acts spatialise the body as a resource of mobile life. Segregating populations for so-called health measures results in hierarchies of being that divide those whose lives will be extended from those who are parts for others and not the self. I suggest that carceral imaginaries capture both the literal architecture of segregation and the body as a space open to so-called institutions of care to use (which often involves abuse) for an imagined greater good that is deadly.

\section{State eugenics and the promise of longevity}

Holmqvist's The Unit paints a viscerally violent picture of a spatialised state of exception through the permanent structures of the clinic-cumprison (Agamben 1998, 168-9). Imagining a carceral society, this fictional text acts as "the residue of a horrific history and the spectre of an unacceptable future but also the unbearable present" (Pollock 2015, 253). Although situated in a futuristic Sweden, Holmqvist's novel is haunted by Sweden's history of eugenics, particularly of the relationship between the disposability of some populations and reproductive rights. The emphasis on reproduction and its relation to national death is brought explicitly to the fore as clinical trials and organ donations are conducted using only women over the age of fifty and men over the age of sixty who have not reproduced. These citizens have not adhered to the national contract of reproductivity and therefore become productive by enabling the lives of others. These biomedical subjects are isolated away from the rest of society, segregated in a prison-like environment, except the unit is a luxurious hotel-cum-clinic. Indeed, most resident donors prefer the luxury of the clinic where they live without the disparaging stares of the successful, read reproductive, citizens, and with the possibility of having both illicit ${ }^{6}$ sexual relationships and a carefree and opulent (short) life.

The Unit presents Agamben's state of exception by capturing how disturbingly discriminating laws - ones that allow for legal murder - may slip easily into mainstream politics. As the main protagonist and narrator Dorrit explains: 
I also remember that [the referendum] wasn't really much of a debate to begin with, because the idea came originally from a newly formed party called the Capital Democrats. [...] The question came up again in different guises and different packaging, and somehow it slipped into the manifestos of some of the bigger and more established parties, and when the referendum finally took place, opinion had shifted. (Unit, 23-4)

This speculative future reflects Mbembe's death worlds where a majority population voted for healthy people to be segregated from humans with children and live as test subjects in clinical trials and eventually die as donors to healthy, reproductive humans. This future scenario proposes an economic model of productivity as a dystopian solution to the organ shortage problem, as well as drawing out the spectres of Sweden's eugenicist history. Since 1997 Sweden has begun to give recognition to the effects of its eugenicist policies, particularly in relation to reproduction. The spectre of this sterilisation programme whose numbers "only Nazi Germany has exceeded" (Broberg \& Roll-Hansen 2005 , ix) - and the fact that over sixty-three thousand people (mainly women) were sterilised from I935 to I975 (Sejersted et al. 200I, II6) - suggests that the novel is linking reproduction, segregation and new biotechnologies both to reflect on historical violence and to engage with the consequences of what may be imagined as scientific progress. I would argue that the clinic is presented as simultaneously the very means through which state-sanctioned murder is facilitated and a space of opulence to capture an important difference between historical forms of segregation and contemporary biotechnological ones. That is, segregation has been theorised as the production of distinct spaces where the oppressor lauds power over the oppressed, generally depriving the oppressed group of essential resources. Indeed, this is how Linda Hogle describes the clinical space during the Nazi era in Germany:

Government euthanasia, internment, and extermination programs allowed clinical and research physicians to use victims - and materials 
from their bodies - as resources for experimentation. The internment of thousands of humans created a controllable environment and easy access to research materials. $(\mathrm{I} 999,49)$

The Unit portrays such an image of the clinic, returning to histories of Swedish clinical practices, but it emphasises how rebellion is kept at bay, or simply how conformity is ensured, by segregating, torturing (through clinical trials) and eventually killing residents in luxurious conditions. Indeed, "carceral imaginaries" (Benjamin 2019) is key here to capture how the freedom in the unit-cum-luxury hotel is the twenty-first century approach to creating space where sexual and intellectual freedom masks the murderous intent of that space. Customer service reigns, giving a veneer of a happy and welcoming environment, but these bodies must be healthy and thus investment in the wellbeing of the residents ensures the future and enduring health of the reproductive human population.

The rationale for this "luxury" and the justification for the fact that the residents are "expensive to run" (Unit, 52) reveal how the Swedish social welfare model, where the government "can be regarded as an institution for social justice” (Gunnarsson et al. 2007, I43) and "welfare is based on general rights that are intended for specific groups of people" (Gunnarsson et al. 2007, I44), has shifted towards a focus on productivity and capital profit. As Dorrit explains:

Anyway: those who safeguard growth and democracy and welfare, they're the ones who own my life. They own everyone's life. And life is capital. A capital that is to be divided fairly among the people in a way that promotes reproduction and growth, welfare and democracy. (Unit, Iо3)

Present and past intersect to reveal both a symbiotic relationship between "massacre and bureaucracy" (Mbembe 2003, 23) and that "sovereignty means the capacity to define who matters and who does not, who is disposable and who is not" (Mbembe 2003, 27). Segregation facili- 
tates ownership over life itself, and thus longevity through biomedicine is achieved by managing productive deaths, deaths that give life to those who reproduce and thereby create future workers. Death is no longer the termination of life for "a person who had no one to live for" (Unit, Io6), because their life was not "a life worth noting, a life worth valuing and preserving" (Butler 2004a, 34). Instead, the person is understood as a "brain-dead body" (Unit, I05), full of life for others and therefore worthy of a good life to ensure that others receive the best health care. This further demonstrates how the redefinition of death - and life itself - as a key tenet in transplant surgery is central to these new death worlds. When Lauren Berlant speaks of "the ethics of longevity [...] in an unequal health system" as a "fantasy bribe that justifies so much exploitation" (Berlant 2007, 764-65), she is considering the poor and vulnerable in the US, but Holmqvist shows how the fantasy of longevity structures space. That is, a biomedical desire for longevity institutes spatialised segregation to ensure a steady supply of research subjects (for clinical trials) and organ donors. Because the welfare state protects all citizens, such divisions cannot be based on gender, race, class or other apparent vectors of power; instead, they are drawn along the lines of productivity, to which all purportedly have access in this free world of state-supported services. The logic of longevity, which is foundational to biomedicine in this novel, requires a disposable population, which must not be discriminated against and therefore must live in luxury whilst being tested on and eventually killed. There is no discrimination, but rather a bureaucratic management of life, where one must do one's duties to the nation or accept life in the luxury of the unit. Bodies are spatialised both through literal segregation from the reproductive and productive population and as units of biomedical experimentation and donation. The promise of longevity - of life-extension - is the biopolitical act of surveilling body parts for the health of the nation and thereby of creating a segregated population deemed less productive and therefore worthy of experimentation and donation to save the healthy, reproductive and productive citizens. Carceral imaginaries are spaces of care and luxury, where those in the unit feel free. Rebellion is unnecessary 
as life endures in comfort, and to escape into the outside world is to reenter the biopolitical regime of normative reproduction and compulsory access to body parts. One would have to live with this violence as the normative structure and constitutive foundation of a long life.

\section{Normative reproduction and inescapable donation}

Redolent of how Foucault describes the architectural structures founding the practices in the clinic, hospital, school, prison and barracks, The Unit portrays clinical subjects as prisoners. They are imprisoned insofar as they cannot leave the confines of the unit, they must comply with the rules of the trials, and they must eventually donate all their organs. However, they express repeatedly that their lives are much freer on the inside than on the outside. More specifically, although there is intensive and relentless monitoring of every movement of each guest (Unit, 3-4), mimicking the panoptic structure of the prison (Foucault I995 [I975]), their gendered and sexual comportment is not, according to the narrator, regulated or forced to comply with Sweden's liberal politics. In this representation of a future Sweden, men can go to prison for "the oppression of a woman and the improper use of male physical strength" (Unit, I29). Outside the clinic, gender equality within a reproductive- and workfocused framework has been achieved:

[D]ay care became compulsory for eight hours a day for all children aged between eighteen months and six years. The housewife and her male provider have not only been out of fashion for a long time, they have been eradicated. [...] There is no longer any excuse not to have children. Nor is there any longer an excuse not to work when you have children. (Unit, 27)

Within this purported egalitarian society, stereotypical gender-based and sexual behaviour is criminalised. To this extent, democratic progress, namely gender equality, necessitates and allows for a reinforcement of normative reproductive sexuality, freed from traditional gender structures but tied to a system of biomedical hierarchisation and dehu- 
manisation. The need for feminist ideas has been abolished by the state's gender equality policies (Unit, 25). Gender-based hierarchies and roles have been outlawed and thus normative heterosexuality -understood as a sexual system that is constitutive of and constituted by a complementary gender dyad structure - is abolished not to bring about social justice as such but to mask a deadlier system where reproduction ensures heightened productivity, where everyone is able to work, creating future workers, and anyone who does not conform is killed at the clinic. Heteronormativity is abolished, bringing with it a new day of mass incarceration where life is monitored along the lines of reproduction and where non-conformity is deadly. The novel instantiates homonationalism (Puar 2013, 2007) and ablenationalism (Mitchell \& Snyder 2015, 2010) insofar as the outlawing of heteronormativity is an egalitarian politics that displaces a questioning of the deadly reproductive politics, and anyone who does not productively contribute to the economy in the form of reproducing and working is then killed. Incarceration is thus a state of exception enforced not through a politics of difference (because gender hierarchies have been outlawed and work laws are fair) or through a punishing isolation, but rather through a comfortable, collective death where sexual and gender freedom is possible. Indeed, contemporary heteronormativity is the so-called freedom desired by the main character.

If Dorrit finds it "beautiful when men show their physical strength openly without being ashamed of it or apologizing" and "when women dare to be physically weak and accept help with heavy jobs", it is only in the clinic where she can "make that choice without being forced to hide it" (Unit, I30). Sex is the means through which freedom is experienced and understood, and defying sexual and gender norms gives a semblance of undoing state power. The novel goes to great lengths to show how what we would today call sexual and gender normativity is exactly what the narrator desires as outlawed practices. Indeed, one could describe the desire for outlawed, heteronormative sexuality and gender roles as queer, and yet the novel shows the limits of such a politics based solely on outlawed genders and sexualities. Such subversion 
does not bring about equality or justice. I would therefore argue that the novel pushes the reader to consider how to resist state violence, particularly when the nation appears to institute feminist and LGBTQ+ policies. Furthermore, the logic of gender equality is unnecessary on the inside because the sense and experience of freedom - for those who have never desired reproduction - ensures conformity, which is reinforced by the fact that they cannot leave the unit. Outside the unit outlawing sexual and gender norms gives the impression of equality - in the sense of moving away from a supposed backward past and to a progressive future of gender equality - but the belief in equality covers over the same hierarchies and divisions that existed and that have simply shifted in relation to reproduction and in so doing have become more deadly.

The Unit is structured through the romance form. At the unit, Dorrit falls in love with Johannes, an "old-fashioned gentleman" who adores her (Unit, 3I). The idealisation of their love, especially that their relationship is viable only on the inside, conforms to the clinic's role in making everyone happy (including gays and lesbians). Indeed, keeping the imprisoned medical subjects satisfied allows for and renders palatable the act of murder. Providing excellent care for valuable resources donor bodies - not only exceeds the donor's needs and previous standard of living, but also shows how the nation cares for those who refuse and/ or are unable to conform to its demands. The clinic disciplines its subjects by creating a spatialised sense of unfettered freedom and thereby makes individuals simultaneously useful and dispensable (Foucault 1995 [I975], 2 I I). Indeed, being confined to a luxurious prison corresponds to what they never had but importantly what they always dreamed of. The unit is the dream, insofar as they may live out their sexual and gendered desires in luxury, but the dream necessitates a violent life and death. In other words, bringing about gender and sexual equality has facilitated a state logic of killing those who do not abide by the laws of this supposedly evolved and egalitarian society. Here, carceral imaginaries involve gender and sexual equality, revealing how an equalities discourse may cover over the violence of state justice. Indeed, luxurious incarceration 
is founded on the very idea of equality that fails to engage with how biohierarchies have not been eradicated but instead shifted to the nonproductive, non-reproductive law breakers.

Dorrit, despite having failed to be either productive or reproductive, still aspires to conform to these parameters of social belonging. On learning of her pregnancy, Dorrit imagines how she could live this longed for life with Johannes and therefore how they could both leave the unit: "Everything was colored by the feeling that I had a man and children and a house and a car and a dog" (Unit, I67). Dorrit's dream, that she and Johannes were "no longer dispensable" and had "become needed", is quickly shattered as she is told, "No, Dorrit. Your child is - at best needed. You are and remain dispensable" (Unit, I86). The horror of these words and that Dorrit can choose either "to donate the fetus for transplantation, or to carry it to full term and then have it adopted" (Unit, I86) is made all the more apparent as the reader, along with Dorrit, learns that Johannes is in the process of being prepped "to donate his liver to a carpenter with three children and six grandchildren” (Unit, I89). Johannes's murder undermines Dorrit's idyllic visions of a life where she, Johannes and their child live the national dream in a reproductive topography. The dream, which could be said to portray her split psychic structure in the way that Frantz Fanon (I967 [1952]) describes the colonised desire to mimic the coloniser, is not attainable for those confined to the clinic.

What is striking about the novel is how resistance is impossible, even unthinkable, precisely because violence is indistinguishable from care and because extending life is central to the economic prosperity and thus healthiness of the nation. Indeed, life is the healthiness of the nation and thus death gives life to ensure its required continuity; there is a homonationalist and ablenationalist agenda that masquerades as gender equality and collective egalitarianism in a nation that must prosper at all costs. Carrying the key given to her by one of the workers at the clinic, Dorrit flees the building, walking away to freedom from the deadly apparatus of the clinic. However, we quickly learn that she returned to the clinic after seeing the stars and later gave birth to her daughter who was subsequently donated to "a single woman [who had] had several miscarriages" 
(Unit, I67). Mbembe suggests that "resistance and self-destruction are synonymous" (2003, 36), specifically under conditions of colonial occupation where the act of suicide is a deadly act of resistance. One could therefore argue that Dorrit's return to the clinic, where she will make her "final donation" after finishing the manuscript that she claims is the text we are reading, is the only act of resistance available to her. Living in the national space is more confining than living in a biomedical environment that demands death for the greater social good. Indeed, the novel makes apparent that segregation from the reproductive and productive society feels less violent than the murder committed on the inside. This is not a celebration of incarceration, as the novel charts the slow cutting of and testing on the characters' bodies over a long time, but instead a visualisation of how harmful a politics of gender equality may be if it ignores other vectors of power, particularly biocapital.

Dorrit's desire to live only until she finishes the text we are now reading suggests that the novel is supposed to record a life rendered meaningless in a society that only values reproductive and productive humans. Giving literary and artistic recognition to an unliveable life is to bear witness to the violence of state care. Yet, the novel remains ambivalent about such potentialities conveying how resistance is absorbed back into a democratic, market-driven system:

[We] live in a democracy, and freedom of expression is one of the cornerstones of a democracy; without the freedom of expression it would collapse. Therefore it is unthinkable to destroy literary or artistic works because the content does not agree with the norms and values of society. [...] We mean nothing; not even those who are needed mean anything. The only thing of any real value is what we produce. Or to put it more accurately: the fact that we do produce something - exactly what it is that we produce is actually of lesser importance, as long as it can be sold or archived. Or preferably both.' (Unit, i 19$)$

Johannes' words show how art, which seeks to undermine or defy state violence, is easily co-opted by the very institutions that enforce the harm. 
This critique serves to reinforce that democracies are open to all voices, even those that question their structures, and that such interrogations are integral cogs of this political wheel. Art is part of this death world where many in the clinic display their works and write their novels - and thus the novel invites reflection on how we remember clinical violence and national histories of abuse, and how we recognise when equality is covering over newer forms of bodily violence. The novel does not provide a solution, but instead portrays the consequences of luxurious and deadly segregation. I would argue that The Unit is an invitation to critique and analyse how a politics of equality may ignore the intersectional vectors of power that mean some populations come to be disposable. Transplantation is, here, a life-extending biotechnology, but it is tied to histories of eugenics and times (past, present and futures) of violence, abuse and the reinforcing of deadly social inequalities. I follow Benjamin's (2019) engagement with carceral imaginaries precisely because this term captures the violence of bioscience and not simply its innovative lifeextending possibilities, as well as her call for "a liberatory imagination [that] opens up possibilities and pathways" (I2). The Unit shows explicitly how the society outside the clinic has been violent to those now residing in this prison-cum-luxury-hotel, and thus that equality cannot only be about outlawing gender and sexual norms, but has to include ways of thinking how past violence is repeated and how biotechnologies are integral to the repetition and reinstituting of deadly hierarchies. Segregating donors from recipients founds the possibility of separating organs from living people, and, in turn, a society that desires life extension only for those deemed as mattering, as productive and reproductive instantiates a deadly politics sustained through spatialised segregation.

\section{Organ segregation and the politics of space}

Organ donation is the lens through which this article explores how lives come to matter and how space institutes and is instituted by the segregated body. I speak of the segregated body to capture how the body politic divides populations through institutions of care and how organs come to be thought of as easily separable from the body in which they reside. 
The implications of thinking the body's parts as separate from the living being are made apparent through the nation which implements a violent but caring segregationist politics. Space as distinct, separate and divided is tied to an imagining of the body as one unit comprised of distinct and donatable parts - and here I have used carceral imaginaries to capture how locking people away in luxury facilitates legal murder. Indeed, the turn to Benjamin's carceral imaginaries has been precisely because I want to show how space is inseparable from how we treat beings and how we decide (often passively as we see in the novel) who may die for others.

The Unit is important for how it captures the historical context of Sweden and yet takes this into our present and future imaginaries. Such histories haunt the nation not only as a shameful past, but also as a prompt to question what happens now. My use of Mbembe's work is important here for thinking how "resistance and self-destruction are synonymous" (2003, 36) particularly when the nation enforces a deadly politics. Writing this article through a global pandemic of COVID-I9 means that such deadly politics are at the fore of what is happening in so many lives. Sweden's high death rates in comparison to the neighbouring Nordic countries has been the source of much discussion, particularly in its laissez-faire politics to the virus that has resulted in high death rates of those in institutions who are often disabled (e.g. Goodman \& Palm 2020; Holroyd 2020; Kartal 2020). The fact that many of the deaths are associated with those in supposed caring institutions reinforces that spatial separation may facilitate and institute a deadly politics. Indeed, the UK-based journalist Frances Ryan has critiqued segregation for disabled people during this pandemic, saying, "A strategy of 'keep the disabled inside', with little to no clarity on what comes next, is as much an attitude problem as a policy one" (2020). Resource allocation is presented - at least in the UK and the US - not as a political decision but as a medical decision based on the likelihood of survival, which is based on ideologies of health and ableism (Chisholm 2020; Leach Scully 2020). Those deemed unlikely to survive were often living with disabilities that would play no role in their capacity to recover from COVID-I9. When people with disabilities and pre-existing conditions in the UK were being called by their general practitioner to be asked to 
agree to a "do not resuscitate" order being placed on their files, it became apparent that saving lives was based on criteria of those who are disposable and those who deserve access to resources because they are imagined as productive (BBC News $202 \mathrm{Ob}$ ). These differing national contexts capture two important concerns of this article: $\mathrm{I}$ ) that institutional segregation often facilitates unequal policies that are deadly towards those in the institutions and that possible resistance to such deadly practices is almost impossible because of how space is organised; and 2) that health based on an economics of profit and scarcity produces death worlds where some are sacrificed for others. Carceral imaginaries capture how spatial segregation is founded on and founds "the life-and-death stakes of technoscience" (Benjamin 2019, 7). While I have not undertaken an analysis of this pandemic, my focus on The Unit aims to unravel how space is central to the organisation of life and death and how queer may help us critique how these institutional practices emerge.

Fiction draws our attention to historical practices that nations prefer to be silent about and, in this case, highlights how those endeavours may reoccur through new technologies. The Unit is particularly important for its incisive critique of gender equality policies and how these may replace one violent structure with another, and it is on this point that I want to conclude. This novel reveals how gender equality may become a normative process that outlaws heteronormativity and its gender dyad basis by instituting a deadly structure of reproductivity and productivity. In other words, reproduction is the production of citizens for the good of the economy, and all have the right to work and reproduce, and all must follow this structure in this equal society. Here, the biopolitics of gender is creating equality through a series of disciplinary acts defined as freedom from harmful normative gender and sexual practices, but it fails to recognise that gender and sexuality are but one part of governmentality and its deadly regime. Such a politics covers over the violence inherent to the democratic machinery whereby freedom is the right to reproduce, be equal and kill others who fail to reproduce so as to render them productive (having failed to be productive by not having children). Segregation is about space: dividing those who are productive and may 
live from those who must become productive by donating their organs. But, segregation is also about the space of the body: imagining the body as made up of donate-able parts, as separate entities that may be mobile, immobilises the body of the donor. Here, the recipient - who we never meet or hear anything about except to know that they reproduce and do productive labour (so is not an artist or an academic in the context of the novel) - needs to be made whole again, while the donor is composed of parts that will sustain the nation's ideology of reproductive productivity. Carceral imaginaries are deadly spatialised regimes of power, where resistance is almost impossible and where the outside world may also be deadly. However, they are also where other possibilities are imagined, and although Holmqvist does not offer a hopeful ending, she does show the work to be done to not reduce change to simplistic gender policies and to not reinforce deadly hierarchies that institute those who may live and those who live and die for others. The novel leaves us with art - both that produced within the novel and the novel as a manuscript from the main protagonist - as the material with which we must decide both how to remember and how to shape our current, uncertain lives. ${ }^{7}$ If death is resistance (Mbembe 2003) in this novel, then the manuscript is a queer question of what is left and therefore how we want to live in this time that is always already haunted by those often unspoken pasts and constituted by what futures are imaginable.

DONNA MCCORMACK is a Chancellor's Fellow at the University of Strathclyde. She currently holds an AHRC Leadership Fellowship on Transplant Imaginaries. Her first monograph is entitled Queer Postcolonial Narratives and the Ethics of Witnessing (Bloomsbury Press 2014), and she has articles in various journals, including Body E Society, European Journal of Cultural Studies, Somatechnics and BMJMedical Humanities, as well as in edited collections such as Bodily Exchanges, Bioethics and Border Crossing (Routledge 2015). She has coedited special issues of Somatechnics and European Journal of Cultural Studies. She is the coordinator of the Nordic Network Gender, Body, Health, as well as a founding member of the Monster Network. 


\section{REFERENCES}

Agamben, Giorgio. 1998. Homo Sacer: Sovereign Power and Bare Life. (Transl. Daniel Heller-Roazen.) Stanford: Stanford University Press.

Ahmed, Sara. 2or 2. On Being Included: Racism and Diversity in Institutional Life. Durham: Duke University Press.

- 2006. "The Non-Performativity of Anti-Racism." borderlands 5(5): I-39.

Baldwin, James. 1963. The Fire Next Time. New York: Dial Press.

Barbarin, Imani. n.d. https://crutchesandspice.com (Accessed May 28, 2020).

BBC News. 2020b. "Coronavirus: GP surgery apologise over 'do not resuscitate' form." https://www.bbc.co.uk/news/uk-wales-52II78I4 (Accessed May 29, 2020).

Benjamin, Ruha. 2019. "Introduction: Discriminatory Design, Liberating Imagination." In Captivating Technology: Race, Carceral Technosciences, and Liberatory Imagination in Everyday Life, edited by Ruha Benjamin. I-22. Durham: Duke University Press.

Berlant, Lauren. 2007. "Slow Death (Sovereignty, Obesity, Lateral Agency)." Critical Inquiry 33(4): 754-80.

Broberg, Gunnar \& Nils Roll-Hansen. 2005 [1996]. Eugenics and the Welfare State: Sterilization in Norway, Sweden, Denmark and Finland. East Lansing: Michigan State University Press.

Butler, Judith. 2004a. Precarious Life: The Powers of Mourning and Violence. London and New York: Verso.

—. 2004b. Undoing Gender. New York: Routledge.

Chan, Sheryl. n.d. https://www.achronicvoice.com (Accessed May 28, 2020).

Chouinard, Vera, Edward Hall \& Robert Wilton (eds.). 20ıо. Towards Enabling Geographies: 'Disabled' Bodies and Minds in Society and Space. New York: Routledge.

Chisholm, John. 2020. "Doctors will have to choose who will get lifesaving treatment. Here's how we'll do it." https://www.theguardian.com/commentisfree/2020/apr/or/ doctors-choose-life-saving-treatment-ethical-rules (Accessed May I8, 2020).

Cohen, Lawrence. 2005. “Operability, Bioavailability, and Exception.” In Global Assemblages: Technology, Politics, and Ethics as Anthropological Problems, edited by Aihwa Ong and Stephen J. Collier. 79-9o. Malden: Wiley-Blackwell.

Cooper, Melinda. 2008. Life as Surplus: Biotechnology and Capitalism in the Neoliberal Era. Seattle: University of Washington Press.

Cooper, Melinda \& Catherine Waldby. 20r4. Clinical Labor: Tissue Donors and Research Subjects in the Global Bioeconomy. Durham: Duke University Press.

Dayan, Colin. 2013. The Law is a White Dog: How Legal Rituals Make and Unmake Persons. Princeton: Princeton University Press.

Diedrich, Lisa. 2007. Language, Politics, and the Culture of Illness. Minneapolis: University of Minnesota Press.

Dimaline, Cherie. 2017. The Marrow Thieves. London: Cormorant Books. 
Fanon, Frantz. 1967 [1952]. Black Skin, White Masks. (Transl. Charles L. Markmann.) New York: Grove Press.

Foucault, Michel. 1990 [1978]. The History of Sexuality: An Introduction. (Transl. Robert Hurley.) New York: Random House.

-. 1995 [1975]. Discipline and Punish: The Birth of the Prison. (Transl. Alan Sheridan.) New York: Random House.

-. 2006 [2003]. Psychiatric Power: Lectures at the Collège de France, 1973-1974. (Transl. Graham Burchell.) New York: Palgrave Macmillan.

Frears, Stephen. Dir. 2002. Dirty Pretty Things [DVD]. UK: Miramax.

Freeman, Elizabeth. 2oro. Time Binds: Queer Temporalities, Queer Histories. Durham: Duke University Press.

Gohlke, Mary with Max Jennings. 1985. I'll Take Tomorrow: The Story of a Courageous Woman who Dared to Subject Herself to a Medical Experiment - the First Successful Heart-Lung Transplant. New York: M. Evans and Company.

Goodman, Peter S. \& Erik Augustin Palm. 2020. “A wave of deaths in Sweden's nursing homes has exposed holes in a famously generous safety net" https://www. nytimes.com/2020/ro/o8/world/a-wave-of-death-in-swedens-nursing-homes-hasexposed-holes-in-a-famously-generous-safety-net.html (Accessed February I5, 2020).

Gunnarsson, Åsa, Eva-Maria Svensson \& Margaret Davies. 2007. Exploiting the Limits of Law: Swedish Feminism and the Challenge to Feminism. London: Ashgate Publishers.

Hogle, Linda F. 1999. Recovering the Nation's Body: Cultural Memory, Medicine, and the Politics of Redemption. New Brunswick: Rutgers University Press.

Holmqvist, Ninni. 2008 [2006]. The Unit. (Transl. Marlaine Delargy.) New York: Other Press.

Holroyd, Matthew. 2020. "Coronavirus: Sweden stands firm over its controversial Covid-I9 approach” https://www.euronews.com/2020/04/o6/coronavirus-swedenstands-firm-over-its-controversial-covid-r9-approach (Accessed April 8, 2020).

hooks, bell. 2009. Belonging: A Culture of Place. New York: Routledge.

Ishiguro, Kazuo. 2005. Never Let $M e$ Go. London: Faber and Faber.

Kartal, Ahmet Gurhan \& Busra Nur Bilgic Cakmak. 2020. "Covid-I9: Sweden's less stringent measures to change" (https://www.aa.com.tr/en/europe/covid-I9-swedens-less-stringent-measures-to-change-/I794325 (Accessed April 8, 2020).

Laing, Lucy \& Rhian Lubin. 2020. https://www.mirror.co.uk/news/uk-news/boysaved-donor-heart-days-21534I4I (Accessed May 15, 2020).

Leach Scully, Jackie. 2020. “Disablism in a Time of Pandemic.” https://www.ghe.law. ed.ac.uk/disablism-in-a-time-of-pandemic-repost-from-ij-fab/ (Accessed May 29, 2020].

Lock, Margaret. 2002. Twice Dead: Organ Transplants and the Reinvention of Death. Berkeley: University of California Press. 
McCormack, Donna. 202I. "The Haunting Temporalities of Transplantation.” Body $\mathcal{E}^{\circ}$ Society $27(2): 58-82$.

-. 2015a. "The Transplant Imaginary and Its Postcolonial Hauntings." In Bodily Exchanges, Bioethics and Border Crossing: Perspectives on Giving, Selling and Sharing Bodies, edited by Erik Malmqvist and Kristin Zeiler. 135-52. London: Routledge.

- 2015b. "Transplant Temporalities and Deadly Reproductive Futurity in Alejandro González Iñárritu’s 2 I Grams.” European Journal of Cultural Studies I9(I): 5 I-68.

-. 20r2. "Intimate Borders: The Ethics of Human Organ Transplantation in Contemporary Film." The Review of Education, Pedagogy and Cultural Studies 34(3-4): 170-83.

Mbembe, Achille. 2003. (Transl. Libby Meintjes.) “Necropolitics.” Public Culture I5(I): I I -40 .

-. 2019. Necropolitics. Durham: Duke University Press.

Mitchell, David T. with Sharon L. Snyder. 2015. The Biopolitics of Disability: Neoliberalism, Ablenationalism and Peripheral Embodiment. Ann Arbor: University of Michigan Press.

-. 2010. "Introduction: Ablenationalism and the Geo-Politics of Disability." Journal of Literary and Cultural Disability Studies. 4(2): II $3-\mathrm{I} 26$.

Moss, Jo. n.d. https://www.ajourneythroughthefog.co.uk/about/ (Accessed May 28, 2020).

National Health Service. n.d.a. "Max: Heart Transplant Recipient and Campaigner." https://www.organdonation.nhs.uk/helping-you-to-decide/real-life-stories/peoplewho-have-benefitted-from-receiving-a-transplant/max-heart-transplant-recipientand-campaigner/ (Accessed May 15, 2020).

—. n.d.b. "Kurran's Story: Kurran Transformed Four Lives When He Died, Aged I9." https://www.organdonation.nhs.uk/helping-you-to-decide/real-life-stories/familieswho-donated-their-loved-ones-organs-andor-tissue/kurran-helped-to-save-thelives-of-four-people/ (Accessed May I5, 2020).

Nelson, Alondra. 20I I. The Black Panther Party and the Fight Against Medical Discrimination. Minneapolis: University of Minnesota Press.

Organ Donation Taskforce, "Organs For Transplants: A Report from the Organ Donation Taskforce.” http://www.wales.nhs.uk/sites3/Documents/753/DoH\%2o Organs\%2ofor\%2oTransplant-A\%2oreport\%2ofrom\%2othe\%2oOrgan\%2oDonation\%2oTaskforce.pdf (Accessed February I2, 2021).

Pollock, Anne. 20r 2. Medicating Race: Heart Disease and Durable Preoccupations with Difference. Durham: Duke University Press.

-. 2015. "On the Suspended Sentences of the Scott Sisters: Mass Incarceration, Kidney Donation, and the Biopolitics of Race in the United States." Science, Technology E Human Values 40(2): 250-71.

Puar, Jasbir. 2013. "Rethinking Homonationalism." International Journal of Middle Eastern Studies. 45(2): 336-39. 
-. 2007. Terrorist Assemblages: Homonationalism in Queer Times. Durham: Duke University Press.

Rusert, Britt. 2019. "Naturalizing Coercion: The Tuskegee Experiments and the Laboratory Life of the Plantation”. In Captivating Technology: Race, Carceral Technosciences, and Liberatory Imagination in Everyday Life, edited by Ruha Benjamin. 25-49. Durham: Duke University Press.

Ryan, Frances. 2020. "When can disabled people leave their homes? It feels like we have been forgotten.” https://www.theguardian.com/commentisfree/2020/may/I I/ disabled-people-homes-lockdown (Accessed May I2, 2020).

Sapochnik, Miguel. 2oro. Repo Men. [DVD]. USA: Universal.

Scheper-Hughes, Nancy. 2005. "The Last Commodity: Post-Human Ethics and the Global Traffic in 'Fresh' Organs.” In Global Assemblages: Technology, Politics, and Ethics as Anthropological Problems, edited by Aihwa Ong and Stephen J. Collier. I45-I67. Malden: Wiley-Blackwell Publishing.

Sejersted, Francis, Madeleine B. Adams \& Richard Daly. 20I r. The Age of Social Democracy: Norway and Sweden in the Twentieth Century. Princeton: Princeton University Press.

Shedd, Carla. 20r r. "Countering the Carceral Continuum: The Legacy of Mass Incarceration." Criminology and Public Policy Iо(3): 865-971.

-. 2015. Unequal City: Race Schools and Perceptions of Injustice. New York: Russell Sage Foundation.

Stark, Tony. 1996. Knife to the Heart: The Story of Transplant Surgery. London: Macmillan.

Sunder Rajan, Kaushik. 2006. Biocapital: The Constitution of Postgenomic Life. Durham: Duke University Press.

Sylvia, Claire with William Novak. 1997. A Change of Heart: The Extraordinary Story of a Man's Heart in a Woman's Body. London: Little, Brown \& Company.

Stoler, Ann Laura. I995. Race and the Education of Desire: Foucault's History of Sexuality and the Colonial Order of Things. Durham: Duke University Press.

-. 2010. Carnal Knowledge and Imperial power: Race and the Intimate in Colonial Rule. Berkeley: University of California Press.

Thompson, Vilissa. n.d. http://www.rampyourvoice.com (Accessed May 28, 2020).

Wailoo, Keith. 200r. Dying in the City of the Blues: Sickle Cell Anemia and the Politics of Race and Health. Chapel Hill: University of North Carolina Press.

Wasson, Sara. 2020. Transplantation Gothic: Tissue Transfer in Literature, Film and Medicine. Manchester: Manchester University Press.

Wilson Gilmore, Ruth. 2007. Golden Gulag: Prisons, Surplus, Crises, and Opposition in Globalizing California. Berkeley: University of California Press.

Wong, Alice. n.d. https://disabilityvisibilityproject.com (Accessed May 28, 2020). 


\section{NOTES}

I. Memoirs on the experience of transplantation, whilst maintaining a positive approach that includes promoting transplantation as a life-saving therapy, tend to be questioning of how positive the experience of transplantation is. See, for example, Mary Gohlke (1985) and Claire Sylvia (1997). On how fiction critically engages with organ transplantation, see Donna McCormack (2012, 2015a and 2015b) and Sara Wasson (2020).

2. On health care provision and its disciplinary structures, see, for example Diedrich (2007); on the racialisation of health care as disciplinary and spatialised power, see, for example: Alondra Nelson (20I I), Anne Pollock (20I2) and Keith Wailoo (200I); and on disability and space, see, for example: David T. Mitchell with Sharon L. Snyder (2015) and Tim Cresswell (1996).

3. This argument comes close to Sara Ahmed's work on non-performativity insofar as the institution says it is doing anti-racist work and therefore the act of saying it stands in for the actual doing of anti-racist work (Ahmed 2006, 201 2). However, my emphasis in this article is on the organisation of life and death, rather than the non-performative structure of purportedly feminist state policies.

4. For powerful and detailed analyses of Foucault and colonialism, see Ann Laura Stoler (I995 and 2010).

5. Pollock is clear that there is a need for ethical discussions concerning "the everyday passively caused deaths of masses of poor people through the denial of care" (2015, 253). In addition, Ruth Wilson Gilmore $(2007,28)$ specifically relates what she calls "premature deaths" to the production of race as difference that in turn produces a series of vulnerabilities.

6. The novel emphasises that normative heterosexuality, which has been outlawed in the outside world, is deeply desired by the main protagonist and can be practised in the unit.

7. There is a huge amount of activism and art around disability and chronic illness both specific to COVID-r9 and beyond. For examples of community building and activism that seek changes and that are often queer in their goals and their practices, see: Vilissa Thompson (n.d.), Imani Barbarin (n.d.); Alice Wong (n.d.), Jo Moss (n.d.) and Sheryl Chan (n.d.). This is without listing the many active and more official organisations that campaign on behalf of people living with illness and/or disabilities. 